University of Nebraska - Lincoln

DigitalCommons@University of Nebraska - Lincoln

8-28-2003

\title{
Biological Control Of Cereal Aphids in North America and Mediating Effects of Host Plant and Habitat Manipulations*
}

\author{
M.J. Brewer \\ N.C. Elliott
}

Follow this and additional works at: https://digitalcommons.unl.edu/usdaarsfacpub

This Article is brought to you for free and open access by the U.S. Department of Agriculture: Agricultural Research Service, Lincoln, Nebraska at DigitalCommons@University of Nebraska - Lincoln. It has been accepted for inclusion in Publications from USDA-ARS / UNL Faculty by an authorized administrator of DigitalCommons@University of Nebraska - Lincoln. 


\section{Biological Control of Cereal Aphids in North America and Mediating Effects of Host Plant and Habitat Manipulations*}

M.J. Brewer

Integrated Pest Management Program, CIPS Bldg., Michigan State University, East Lansing, Michigan 48824; email: brewerm@msu.edu

\section{N.C. Elliott}

U.S. Department of Agriculture, Agricultural Research Service, Plant Science Research Laboratory, Stillwater, Oklahoma 74075; email: nelliott@pswcrl.ars.usda.gov

Key Words classical biological control, conservation biological control, tritrophic interactions, plant diversity, landscape diversity

- Abstract The predator and parasitoid fauna associated with cereal aphids is described, emphasizing the fauna associated with classical biological control efforts against the greenbug and Russian wheat aphid. We focus on literature from North America and include work from Europe and elsewhere when it is desirable to draw contrasts between approaches that affect cereal aphid biological control. Effects on natural enemies of cereal aphids are described that appear associated with plant traits that are innate, bred, or induced by aphid feeding. Examples of habitat manipulations, within and bordering cereal fields and within the broader landscape in which cereal production resides, affecting predators and parasitoids of cereal aphids are presented. These mediating effects of host plant and habitat manipulations on cereal aphid biological control provide significant and underexplored avenues to optimize cereal aphid management.

\section{INTRODUCTION}

Severe damage to cereals caused by two cereal aphid species [greenbug, Schizaphis graminum (Rondani), and Russian wheat aphid, Diuraphis noxia (Mordvilko) has led to substantial classical biological control efforts in North America from the late 1960s through the mid-1990s $(52,108)$. Because of the wide climatic and geographic conditions, changing production systems under which cereals are grown, and concentration of damage by cereal aphids in the rain-fed cereal

\footnotetext{
*The U.S. Government has the right to retain a nonexclusive, royalty-free license in and to any copyright covering this paper.
} 
production region of the Great Plains grassland region of the United States and Canada $(33,65)$, this region is highlighted.

Aphid-natural enemy interaction studies and surveys of natural enemies of cereal aphids have been carried out in conjunction with classical biological control programs to control the greenbug and Russian wheat aphid (7, 50, 80, 111). Studies of natural enemy-aphid-plant-habitat interactions are a special focus of this review. The vast majority of research comes from Europe and much of it has been reviewed $(17,19,138,147,148)$. We focus primarily on literature from North America and include the work from Europe and elsewhere when it is desirable to draw contrasts between approaches that affect cereal aphid biological control. In North America, studies of natural enemy-aphid-plant-habitat interactions have substantially increased since the mid-1980s, resulting in part from these classical biological control programs, from efforts in cereal breeding for aphid resistance, and from interests in agroecosystem diversification $(7,32,110)$.

\section{APHID AND NATURAL ENEMY FAUNA}

\section{Key Cereal Aphids and Their Predators and Parasitoids}

The greenbug is the most important damaging cereal aphid in the Great Plains of North America. Reports of its damage to wheat begin in the early 1900s and outbreaks have occurred periodically since (119). Its annual host plants are restricted to about 70 species of the Poaceae, occurring in 44 genera. Holocyclic and anholocyclic generations can occur on the same hosts, but greenbugs must migrate among hosts to remain viable year-round (94). The greenbug is a persistent pest in the southern and central Great Plains, where the primary cereal crops are winter wheat and grain sorghum. Both anholocyclic and holocyclic generations occur in this region. Management efforts have focused on breeding of small grains resistant to greenbug and use of insecticides. Subsequent emergence and spread of greenbug biotypes able to feed on and damage resistant grains have resulted in continuing outbreaks (143). Annual losses caused by greenbugs have not been estimated for the entire Great Plains region but range roughly from $\$ 10$ to $\$ 250$ million dollars depending on the year $(119,142)$.

The Russian wheat aphid was first detected in the United States in Muleshoe, Texas, in March 1986 (125), spreading to 16 western states of the continental United States and two provinces of Canada within a few years. It is anholocyclic throughout its range in North America. Its host range is restricted to the Poaceae, with approximately 40 species of small grains and cool-season grasses serving as highly suitable hosts (78). Russian wheat aphid caused widespread loss to the small-grain industry, principally winter wheat and spring barley grown in the western edge of the Great Plains and spring wheat and barley grown in the northwestern states of the continental United States. Economic losses in the Great Plains account for about $65 \%$ of the losses in the region (32). The Russian wheat aphid was a severe pest from the mid-1980s through the mid-1990s in the southern 
and central-western edges of the Great Plains, which are characterized by low precipitation, high elevation, and favorable oversummering of the aphid in the northern zones of the region and favorable overwintering in the southern zones (32). Russian wheat aphid populations and damage have declined in much of its range since the mid-1990s $(1,8)$.

Whereas the greenbug and Russian wheat aphid are the most economically important aphid pests of wheat, the English grain aphid, Sitobion avenae (F.), bird cherry-oat aphid, Rhopalosiphum padi (L.), and corn leaf aphid, Rhopalosiphum maidis (F.), also infest wheat, barley, and oats in the Great Plains and northwestern United States. Economic injury on cereals caused by these species is uncommon $(77,101)$.

Cereal crops in North America are inhabited by numerous species of aphid natural enemies. Many Coccinellidae are relatively specialized predators of aphids and occur in cereals throughout North America, although the occurrence and importance of particular species vary regionally. Some important species are Hippodamia convergens Guerin-Meneville, Coccinella septempunctata L., and Coleomegilla maculata DeGeer $(33,92)$. Flower fly larvae (Syrphidae) prey on aphids, whereas adults feed on nectar, pollen, and aphid honeydew. Larvae of the Chamaemyiidae are known to prey upon cereal aphids $(26,130)$. The host ranges of these species can include some use of non-aphid prey, but they broadly can be classified as aphid specialists, at least when compared to spiders, carabids, and staphylinids. Only a few species of green lacewings (Chrysopidae) inhabit cereal fields in the United States; the common green lacewing, Chrysoperla plorabunda (F.), is the most common and widespread species. Green lacewings that inhabit cereals are predaceous only as larvae. Adults feed on aphid honeydew, nectar, and pollen. Brown lacewings (Hemerobiidae) sometimes also occur in cereals and feed on aphids but are generally less abundant than chrysopids. Predatory Heteroptera (Nabidae and Anthocoridae) feed on aphids in cereals. Both adults and immatures are predaceous. The common damsel bug, Nabis americoferus Carayon, is widely distributed in small grains and other crops and is frequently among the most abundant predatory insects in cereal fields. Adult $N$. americoferus are winged and highly mobile. They effectively prey upon aphids but lack high prey specificity $(33,81)$. Primary hymenopterous parasitoids of several genera of the Braconidae (Aphidiinae) and one genus, Aphelinus, of the Aphelinidae specialize on aphids, including cereal aphids $(31,53,72,102,108)$. Coccinellids, chrysopids, hemerobiids, syrphids, braconids, aphelinids, and to a lesser extent nabids and anthocorids compose the specialist natural enemy fauna utilizing cereal aphids in North America.

Ground beetles (Carabidae), rove beetles (Staphylinidae), and spiders (Araneae) are abundant generalist predators in cereal fields, many of which feed at the soil surface. They are primarily ground dwelling. However, they can feed extensively on cereal aphids, which often occur on the soil surface as the result of intentional dispersal among plants or unintentional dislodgment from plants caused by wind, rain, activity of predators and parasitoids, and other factors $(55,145)$. Some predaceous species of Neuroptera and Heteroptera that feed on aphids in cereals have 
a broad range of prey, including aphids, plant bugs, thrips, mites, and eggs and larvae of Lepidoptera and Diptera $(15,81,82)$. Enemies of specialist and generalist predators and parasitoids of cereal aphids exist and have been generally characterized $(27,83,148)$.

\section{Classical Biological Control Efforts}

A classical biological control program for the greenbug was first considered in 1968 when the first severe outbreak of biotype $\mathrm{C}$ greenbug occurred on sorghum throughout the Great Plains. In response, exploration was initiated for natural enemies from eastern and western European countries, Iran, Pakistan, and Chile. The program resulted in the importation of 11 species of hymenopterous parasitoids (52). Six of these species, Aphelinus asychis (Walker), Aphelinus varipes (Forester) (Aphelinidae), Aphidius matricariae Haliday, Diaeretiella rapae (McIntosh), Ephedrus plagiator (Nees), and Praon pakistanum Kirkland (Braconidae: Aphidiinae), were released one or more times in Oklahoma, Texas, and other Great Plains states (52, $72,73,113)$. Permanent establishment of released parasitoids was not confirmed for any of these species in extensive surveys in Oklahoma and Texas. Several species of exotic Coccinellidae were also released. Although C. septempunctata is currently established in the region, it probably did not establish from releases made against greenbug but rather spread from the eastern United States, where it established from intentional or unintentional releases during the 1970s (114).

Field surveys of greenbug parasitoids in wheat and sorghum in the southern Great Plains before and after the classical biological control program for the greenbug yielded predominately the braconid Lysiphlebus testaceipes (Cresson), with the braconid D. rapae (McIntosh) and the aphelinid A. varipes (Forester) (=Aphelinus nigritus Howard) occurring much less commonly but occasionally dominating $(2,53,72,79,126,140)$. Because $D$. rapae and $A$. varipes were present prior to the classical biological control program, establishment of introduced strains of these two species could not be confirmed. A. asychis was recovered after release and was not known to occur before the release effort, but it was never found in later surveys $(73,113)$. Thus, introduced parasitoids for greenbug control appear to contribute little to biological control of greenbugs in wheat and sorghum in the region.

A classical biological control effort was initiated in response to the introduction, spread, and economic impact of Russian wheat aphid on small grains in North America $(69,108)$. Greater than 15 million specimens of predators (Coleoptera: Coccinellidae; Diptera: Chamaemyiidae and Syrphidae) and parasitoids (Hymenoptera: Aphelinidae and Braconidae: Aphidiinae) were released in 18 U.S. states and Canadian provinces for nearly 10 years beginning in 1987 $(102,108)$. In Washington and Idaho, seven species of parasitoids were released, and after six years recoveries of three species, Aphelinus albipodus, Aphidius uzbekistanicus Luzhetzki, and Praon gallicum Starý, were attributed to the release program $(57,102,108,131)$. Several other species were released in the biological 
control program and later recovered, most commonly D. rapae, but they were previously known to occur in the region and could not be distinguished from those released. At least 11 braconids and 3 aphelinids have been reared from Russian wheat aphid and other cereal aphids in Washington $(4,37,57,102,103,131)$.

In the southern region of the Great Plains in Colorado and Texas, three aphelinids and two braconids that attack Russian wheat aphid were recovered three or more years after release of at least four parasitoids to control Russian wheat aphid. One aphelinid, A. albipodus, could be attributed to the release effort, because it was neither found in prerelease surveys nor reported in the region before release. One braconid, D. rapae, could be a result of the introductions or adaptation of previously existing populations to Russian wheat aphid (10, 31, 93). In northcentral Colorado, southeastern Wyoming, and southwestern Nebraska, ten parasitoids were released. Seven years after release and 10 years after first detection of Russian wheat aphid, A. albipodus was attributed to the biological control effort, and $D$. rapae presence may have been associated with the releases or populations previously known $(1,8,10,95)$. In this area, $D$. rapae was more common than $A$. albipodus in the early 1990s, a few years after first detection of Russian wheat aphid and introduction of parasitoids, and A. albipodus became the more abundant species by the mid-1990s (8).

Efforts were made to establish predators (chamaemyiids, syrphids, and coccinellids) (108). Subsequent to the release effort, species of chamaemyiids (at least 1 species, Leucopis gaimarii Tanasijtshuk), syrphids (at least 4 species), and coccinellids (at least 11 species) have been detected in cereal fields (91, 92, 95, 130). It is doubtful that any of the predator species recovered were the result of releases made during the biological control program to control Russian wheat aphid, because they were representative of endemic species or species released as part of earlier biological control efforts $(33,91,92,95,130)$.

Parasitoids released and established for classical biological control of the Russian wheat aphid also parasitize the greenbug $(92,93)$. In the north Texas Great Plains, the aphelinids A. asychis and A. albipodus parasitized greenbugs in winter wheat, but they were not sufficiently abundant to provide a measure of suppression (92). These species have not been observed parasitizing greenbugs in wheat fields in Oklahoma $(50,75)$.

It is arguable whether the classical biological control efforts against the greenbug and Russian wheat aphid contributed substantially to the effect of preexisting native and previously introduced natural enemies. Given the current extent of the coccinellid fauna in the cereal agroecosystem in the southern Great Plains, it has been proposed to delay additional introductions of coccinellids if a new cereal aphid invades the region in order to determine if preexisting coccinellids will adapt to and aid in the control of a new aphid (92). This argument can be extended to planning of future parasitoid introductions for cereal aphid control, although adaptation onto new aphid hosts may be more problematic for parasitoids given the probable existence of strains, sibling species, and habitat specificity within nominal species $(49,107)$. 


\section{THE ROLE OF NATURAL ENEMIES IN CEREAL APHID CONTROL}

\section{Generalist Predators}

The importance of generalist predators in biological control was recently reviewed (129). Published studies show significantly reduced pest density in about $78 \%$ of the cases in annual crops, some of which apply to cereal aphids. European work largely supports that generalist predators can suppress or contribute to the suppression of cereal aphid infestations if they are present in high-enough density early in the growing season, when aphids are colonizing cereals $(20,30,148)$. By killing cereal aphids that fall from plants, either by direct predation or by trapping aphids in webs, spiders and other polyphagous predators reduce aphid populations in European cereal fields $(24,128)$. A few carabid species, such as Pterostichus cupreus L., are also known to climb plants to prey upon aphids (21). Early-season predation can markedly reduce aphid density at population peaks later in the season. Predation by generalist predators later in the growing season, when warm weather permits rapid growth of aphid populations, provides insufficient mortality to substantially reduce aphid density $(12,20,30,64,148)$.

The role of generalist predators in suppressing greenbug and Russian wheat aphid in the Great Plains of North America has not been evaluated, although some contrasts with the European fauna can be made. There are substantial differences in climate and agronomic circumstances between the cereal-growing regions of western Europe and the Great Plains, which are reflected in the generalist predator fauna. Spiders are much less abundant in the western edge of the Great Plains, which is a semi-arid region with water being a principal limiting factor in cereal grain production. In Europe, spider relative abundances are more evenly distributed $(56,100)$. Numerous species of ground beetles and rove beetles can be found in cereal fields in North America and Europe, and the species composition varies over the course of the growing season $(25,43,141)$, but only the extensive European work provides the accumulated evidence of their impact on cereal aphids $(20,30,148)$.

\section{Aphid Specialist Predators and Parasitoids}

Most research on specialist natural enemies of greenbugs in North American cereal fields has focused on the roles of coccinellids and hymenopterous parasitoids in suppressing greenbug infestations. Conclusions of various studies differ markedly. Exclusion cage studies in Texas demonstrated that predatory coccinellids were primarily responsible for greenbug suppression in grain sorghum (80). In Kansas, coccinellids and parasitoids individually and in combination suppressed greenbug densities in particular experiments in grain sorghum (111). In both Kansas and Texas, suppression of greenbug in winter wheat was attributed primarily to predation by large predators, mostly adult coccinellids $(92,111)$. Additional work manipulating greenbug densities on grain sorghum in field cages indicated greenbugs began to decline when parasitism rates by the braconid L. testaceipes 
reached $20 \%-30 \%$. When initial densities of 20 greenbugs per 0.5 adult $L$. testaceipes per plant were introduced in cages, suppression occurred before greenbug density reached the economic threshold of 1000 greenbugs per plant (38). In winter wheat fields in Oklahoma, parasitism rates by L. testaceipes exceeded $20 \%$ in 15 of 21 fields before greenbugs had exceeded an economic threshold of 9 greenbugs per tiller. In 13 of 15 fields with greater than $20 \%$ parasitism, greenbug infestations remained below the economic threshold throughout the growing season (50).

In an analysis of previously published data (91), Gilstrap (51) proposed a scenario that reconciled conflicting results on the relative roles of specialist predators and parasitoids in controlling greenbugs in grain sorghum. According to his analysis, coccinellids are drawn into sorghum fields to feed on corn leaf aphids that colonize sorghum soon after emergence. These aphids typically do not injure the sorghum. Coccinellids are still present in the field when greenbugs colonize later in the growing season. Predation by coccinellids slows the rate of greenbug population growth so that greenbug populations are well below the economic threshold when parasitoids colonize the field later in the growing season. When greenbug density is low as the result of predation by coccinellids, L. testaceipes and other parasitoids can maintain greenbug infestations below the economic threshold. Presumably, it is the joint occurrence and seasonal progression in sorghum fields of corn leaf aphids, coccinellids, and parasitoids that facilitates effective biological control of greenbugs in grain sorghum. This scenario is consistent with others describing the importance of neighboring crops, grasslands, and field borders serving to conserve natural enemies of cereal aphids, as well as other natural enemies of insect herbivores of annual crops $(1,139,146,149)$.

Field exclosure experiments in Europe and North America indicate that natural enemies play an important role in regulating Russian wheat aphid populations. In France, peak Russian wheat aphid densities were 10- to 18-fold greater when natural enemies were excluded than when in open-caged plants and uncaged plants (68). Preliminary reports from studies in the Great Plains using similar methods indicated 2- to 19-fold differences between exclusion cages and open cages or uncaged plants (67). The latter study was conducted after natural enemy releases from the classical biological control program against Russian wheat aphid; however, the relative importance of preexisting versus introduced natural enemies was not provided in the report.

The importance of other specialist predators in biological control of cereal aphids in North America has not been determined. In Europe, syrphids are considered important in suppressing cereal aphid infestations, and adding flowering species in and directly adjacent to cropped lands benefits syrphid activity $(18,132,133)$. Species of another family of predatory fly (Chamaemyiidae) are not commonly encountered or recognized possibly owing to their inconspicuous behavior and morphology compared with syrphids. Both European and North American species are known, but their impact on aphids in cereal fields is not known $(48,130)$. The damsel bug, $N$. americoferus, and other predatory bugs may be 
important enemies of cereal aphids because of their high densities in cereal fields, but delineation of their impact is needed $(33,81)$.

\section{MEDIATING EFFECTSOF PLANT HOST FACTORS ON BIOLOGICAL CONTROL}

\section{Terminology and Early Indications of Tritrophic Effects}

Plant chemistry and structure and those plant responses induced by herbivory affect a broad array of natural enemies of insect herbivores. Plant structure and chemical composition may directly affect the natural enemy's ability to find, select, and utilize its prey. Plant features that may indirectly affect a natural enemy include poor nutrient content, antibiotic constituents, and structure that disrupts aphid biology (e.g., aphid size, reproduction, feeding behavior, and location) $(3,5,115)$.

Early experimental indications of tritrophic interactions come from studies involving cereal aphids and their natural enemies (3). Reducing the rate of reproduction of multivoltine species such as aphids should lead to increased effectiveness of their natural enemies (137) if antibiotic plant factors do not significantly impede natural enemy fitness and prey use. In an early greenhouse study, a barley cultivar that slowed the reproduction of greenbug benefited a parasitoid's (L. testaceipes) ability to further slow aphid population growth. An indirect effect of lower-weight, mummified aphids occurred on the resistant plants, which were correlative with sublethal effects of greenbugs feeding on the resistant plants, but there was no evidence of direct effects of the resistant plant on L. testaceipes. On balance, parasitoid effectiveness in regulating greenbug was increased when acting jointly with a resistant plant that had partial antibiotic effects on the aphid and parasitoid (116, 120, 121). Cereal aphid resistance based strictly on tolerance traits should not affect herbivore fitness, as plant damage is lowered compared with damage incurred by a susceptible plant $(143,144)$; therefore, negative effects on the third trophic level would be unlikely (110). Partial tolerance resistance and combined tolerance and antibiosis resistance add further complexity to possible effects on the third trophic level. Partly attributed to the number of cereal cultivars developed with resistance to aphids (143) and increased interest in use of natural enemies to control cereal aphids $(52,69,108)$, additional studies have become available in the past few decades to gauge the direct and indirect effects of plant characteristics on natural enemies and more broadly the compatibility of aphid-resistant plants on cereal aphid natural enemies. Plants of similar genetic background, of unknown similarity but of the same species, and of different species have been used in these studies.

\section{Comparisons Using Aphid-Resistant Plants of Similar Background}

The ability to separate causes of tritrophic effects should come from comparing cereal aphid-natural enemy interaction on plants differing in aphid resistance with 
an otherwise near-isogenic background or on different plant structures of a single plant species. One study (90) identified in this review states that the wheat lines compared were of near-isogenic background, differing in a gene conferring tolerance to Russian wheat aphid. In this case, susceptible plant responses indicative of Russian wheat aphid-feeding damage (i.e., inability of new leaves to fully expand, leaf chlorosis, and leaf streaking) were suppressed in the resistant wheat line. A lacewing predator, C. plorabunda, was provided little to no additional benefit in preying upon Russian wheat aphid on the resistant line, where the aphid occurred on unfolded leaves and leaf whorls, compared with preying upon Russian wheat aphid on the susceptible line, where the aphid occurred in leaf curls induced by aphid feeding. Here, a tolerance characteristic did not affect the predator to any significant degree, even though decreased damage to the resistant line, with aphids occurring on the fully expanded leaves, could arguably increase predator access to prey (90). Others comparing predation and parasitism of corn leaf aphid, bird cherry-oat aphid, Russian wheat aphid, and rose-grain aphid, Metopolophium dirhodum (Walker), occurring on leaf and seed structures of a single species found that aphids feeding within curled leaves, whorls, and between seeds were protected to varying degrees from selected braconids and coccinellids. When differences were detected, restricted access to aphids best characterized the interactions, and when behavioral observations were taken, no effect on enemy foraging behavior was indicated $(49,54,76)$.

\section{Comparisons Using Aphid-Resistant Plants with Unknown Similarity}

A more extensive literature base provides comparison of cereal aphid-natural enemy interaction on plants differing in aphid resistance with otherwise unknown differences in genetic background. Here, contributions of individual plant characteristics toward the interaction cannot be strictly assigned, but putative resistance characteristics with a priori expectations of the form of the interaction have been put forward. Tolerance resistance, associated with the ability of resistant lines to expand their leaves in the presence of Russian wheat aphid, has been reported to increase parasitism by the braconid $D$. rapae on slender wheatgrass (109) and predation by the coccinellid Scymnus frontalis (F.) on wheat (34). In other studies parasitism and predation of Russian wheat aphid on wheat and barley with this apparent form of resistance were compatible (no interference). Synergistic action was not detected, as would be expected if natural enemy access to aphids in folded leaves was restricted $(9,90)$. The relationship of physical size of the enemy and the plant structure where Russian wheat aphids feed has been proposed as a mechanism governing this interaction (76), but insect behavior, such as ovipositional behavior of the natural enemy, may provide access to apparently concealed aphids. Laboratory observations of the predatory fly L. gaimarii (Chamaemyiidae) provided evidence of its ability to oviposit in leaf curls where aphids occur (48), and field and laboratory observations of mummified Russian wheat aphids in leaf 
curls $(7,9,37)$ suggest that ovipositional behavior of the parasitoid or the degree of concealment of the aphid prey may enable utilization of the aphid prey. Wheat and barley leaves of susceptible lines are strongly to partially curled in response to Russian wheat aphid feeding even within the same cultivar (11). Leaves partially curled may allow aphid access to parasitoids (9), whereas more tightly curled leaves of other plant species may impede parasitoid access (109). Behavioral observations of parasitoids seeking aphids on plants that have been damaged or otherwise responded to aphid feeding would benefit this analysis.

Antibiotic plant factors acting alone or in combination with tolerance traits may affect cereal aphid natural enemies. DIMBOA, a secondary metabolite found in wheat resistant to cereal aphids, is a feeding deterrent and decreases weight of bird cherry-oat aphid and English grain aphid. The coccinellid Eriopis connexa Germar and the braconid parasitoid Aphidius rhopalosiphum De Stephens-Perez using aphids fed DIMBOA-containing wheat showed increases in development time and other impairments $(44,85,98)$. Other aphid-resistant cereals, such as sorghum and wheat, with unspecified antibiotic factors that reduced aphid growth and reproduction also appeared to disrupt the development of the coccinellid Hippodamia convergens and the parasitoid D. rapae $(110,111)$. But there were other cases in which L. testaceipes and D. rapae utilized greenbug and Russian wheat aphid with little disruption on wheat and triticale with antibiotic resistance properties $(120,121)$ and no measurable disruption of $D$. rapae across multiple parasitoid generations $(35,36)$.

The combined effects of parasitoids and aphid-resistant cereals in lowering aphid population growth rates can be further benefited or negatively affected by the action of entomopathogenic fungi infecting aphids, depending upon the timing of parasitoid oviposition and fungal infection $(45,46,106)$. Disruption of aphid feeding on resistant plants may also lead to an increase in aphids falling from leaves and onto the ground, where they are exposed to ground-dwelling predators and other abiotic mortality factors $(55,86)$. This disruption increases on partially resistant wheat (55), corresponding with known aphid feeding behavior disruption on partially antibiotic wheat and barley $(55,144)$.

\section{Comparisons Using D ifferent Plant Species}

Additional studies compared cereal aphid-natural enemy interaction across plant species and may be useful in assessing the range of potential tritrophic effects. Crested wheatgrass and Indian ricegrass, whose leaf shapes were flat and tightly curled at maturity, respectively, affected predator accessibility to aphids. Naturally occurring leaf curls that are tight may shift feeding sites of Russian wheat aphids that normally would feed inside a folded leaf. This feeding-site shift increased predation by several chrysopids [Chrysoperla carnea (Stephens) and C. plorabunda] and a coccinellid [Propylea quatuordecimpunctata (L.)] (23, 87-89).

Tests using cereal breeding lines that are near isogenic and differ only in a single trait with potential tritrophic effects are generally lacking in the study of cereal aphids-natural enemy interactions; therefore, statements on the cause of 
tritrophic effects are not definitive. Given this caveat, effects on natural enemies of cereal aphids have been detected that appear associated with tolerance-related and antibiotic plant characteristics that are innate or induced by aphid feeding.

\section{MEDIATING EFFECTS OF WITHIN-FIELD MANIPULATIONSON BIOLOGICAL CONTROL}

\section{General Diversity Structure and Natural Enemy Ecology}

Reviewing effects of habitat diversification on spiders, Sunderland \& Samu (127) make a useful distinction between dispersed and aggregated plant diversity. Dispersed diversification includes practices such as undersowing, partial weediness, and reduced tillage applied more or less uniformly across a field, whereas aggregated diversification includes practices such as intercropping and planting noncrop plants in strips within a field or in field edges. The effects of dispersed and aggregated diversity differ depending upon the form of the diversity and natural enemy ecology. For example, spider abundance in crops was increased in 33\% of published studies involving aggregated diversity compared to $80 \%$ involving dispersed diversity (127).

Some predators colonize agricultural fields from relatively long distances, and others enter from field edges. For example, liniphyiid spiders and some staphylinid beetles disperse by ballooning and flying, respectively, and colonize agricultural fields from habitats in the surrounding landscape. Other predators, including many carabids and lycosids, disperse by walking and colonize fields more slowly from immediately adjacent habitats $(25,29,141)$. Many carabids, lycosids, and other generalist and specialist predators overwinter in field boundaries and have high overwintering survival in grassy vegetation frequently growing there $(117,118)$. These predators disperse into cereal fields from boundaries and exhibit a distinct edge effect, with highest densities near the boundary that decrease with distance into the field $(6,25)$. For large cereal fields the ratio of edge to area is small and the density of predators that enter from the boundary would be low compared to smaller fields. Furthermore, the highest densities would occur near the field border, with lower densities in the field interior (29). To overcome this problem, grass strips called beetle banks have been planted in fields (aggregated diversity) to increase predator densities. The strips provide habitat for overwintering and increase the colonization rate of the field by predators in spring (135). A similar approach creating strips of mixed grassy and herbaceous vegetation was proposed by Nentwig (96).

Vegetation strips have favorable microclimate for survival of generalist predators, and alternative prey and perhaps other resources, during winter and during the growing season, resulting in higher densities of generalist predators in cereal fields $(22,74,84,117,118,135)$. The increased densities can result in higher predation on cereal aphids in the crop by some predators, at least in close proximity to the strips $(24,59)$, but this is not true for all predators (74). The primary limitation 
of within-field strips is that many predators disperse only a short distance into the field $(74,84)$ or not at all (16) from the apparently preferred habitat provided by the strips. Frank \& Nentwig (40) attempted to reconcile differences pertinent to a particular system and determined the optimal distance between weed strips in a cereal field in Germany to be approximately $24 \mathrm{~m}$ for maximizing densities of spiders and carabids.

\section{Approaches to Attaining Aggregated Diversity in Cereal Fields}

Studies of noncropped weed or grass strips on generalist predators in cereals in Europe include recommendations of the width and dispersal of strips in large cereal fields $(40,97)$. Use of noncropped vegetation to attain aggregated diversity in the Great Plains of North America has not been undertaken. Cereal fields are generally larger and grain yields lower in the Great Plains than in western Europe. The low profit margins associated with cereal production in the Great Plains necessitate low input costs for pest management (65). Costs involved with habitat manipulations involving noncropped species, as done in Europe, would not be cost-effective in most cereal production in North America, with the possible exception of the high cereal productivity areas of the midwestern and northwestern United States. Therefore, the greatest potential for habitat manipulation in most cereal production in North America involves the use of grain crops that can be grown in crop rotation with cereals, and adjacent plantings of grasses used for forage or soil and wildlife conservation $(1,28)$.

Arguably comparable approaches to aggregated field diversity practiced in Europe take the form of intercropping in the Great Plains. Relay intercropping involves the use of crops with overlapping growing seasons to maintain resources needed by natural enemies in the cropping system. In a winter wheat, sorghum, and cotton relay intercropping study (approximately 4-m-wide strips) in the Texas Great Plains, coccinellids, lygaeids, chrysopids, anthocorids, and nabids densities were greater, and cotton aphid, Aphis gossypii Glover, density was lower in the relay intercropped system than in a monocrop (99). Presumably, natural enemies were more abundant in the intercropped wheat, but natural enemies were not measured in monocropped wheat to allow comparison. A relay intercropping system involving winter wheat and cotton is widely used in northern China. The primary benefit of this system is reduced damage to cotton from the cotton aphid caused by natural enemies that disperse from wheat into cotton (150). As with the Texas system, predators from cotton probably colonize wheat where they reduce cereal aphid populations.

In the western edge of the central Great Plains, winter wheat is the predominant rain-fed crop and is usually grown in a wheat-fallow rotation spatially arranged in elongate alternating strips of wheat and fallow (about $30-90 \mathrm{~m}$ in width) that are rotated yearly. Aggregated diversity occurs in these systems as spatial rotations planted in alternating strips of winter wheat, fallow, and one or more additional spring-sown crops such as sunflower, dryland corn, sorghum, or millet. A 
three-year wheat-fallow-alternate crop rotation was originally designed to alleviate limitations associated with the traditional wheat-fallow rotation by increasing water use efficiency and profitability $(28,100)$. The braconid D. rapae and aphelinid A. albipodus parasitized more Russian wheat aphids in wheat intercropped with sunflower than in wheat-fallow rotations. In this case there was not year-round overlap of the crops grown, but the length of time crops were not in the field was reduced to about one month or less compared to about two to three months in the wheat-fallow system (1).

In Europe, studies have addressed the effects of fine-grained intercropping (oats and faba bean in a mixed planting) on natural enemies in cereals. Coccinellids and parasitoids were either unaffected or decreased in density in oat-faba bean mixed cropping (61), whereas densities of several generalist carabids were increased (60). Aphid numbers per oat tiller increased in intercrops by about the planting ratio of faba bean to oats, suggesting that the main effect on the aphids was simply the concentration of the same number of colonizing aphids on fewer tillers per unit area. Coccinellid densities remained constant between monocropped and intercropped oats.

In a study where the boundary of a wheat field was segmented into herbicidetreated and untreated sections measuring $50 \mathrm{~m}$ in length, sections of the boundary left untreated had greater syrphid densities, and oviposition by syrphids was greater in the weedy sections than in the herbicide-treated sections. However, there was no increase in the density of syrphid eggs in the interior of the field adjacent to untreated sections (26). When the flowering plant Phacelia tanacetifolia Bentham was planted along the entire field boundary, significantly more syrphid eggs and significantly fewer aphids were found in fields with $P$. tanacetifolia boundaries than in control fields (63). Thus, at a sufficiently broad spatial scale it was possible to demonstrate the redistribution of adult syrphids into fields with favorable habitat, an increased recruitment in the fields, and an increase in the level of biological control.

\section{Approaches to Attaining D ispersed Diversity in Cereal Fields}

Studies of dispersed diversity in cereals created by reduced tillage usually find increased density of generalist predators with decreasing levels of tillage $(42,70)$. However, Huusela-Veistola (71) did not observe a change in generalist predator density with reduced tillage. In the Great Plains, wheat and sorghum grown using reduced tillage and no tillage have lower greenbug density than conventionally tilled fields $(13,14)$. The primary mechanism involved is thought to be the reflective properties of crop residue for incident light, which reduces the landing rate of airborne dispersing greenbugs. The role that natural enemies play in reducing greenbug densities in reduced tillage fields has not been investigated. However, in Kansas, coccinellids and chrysopids had densities in reduced tillage plots that were similar to and sometimes lower than densities in conventional tillage plots. Spiders were the only generalist predators sampled, and the densities in reduced tillage plots were sometimes higher or lower than densities in conventional tillage plots (112). 
The effects of weeds and undersowing with legumes or grass within the cereal crop on cereal aphid natural enemies have been examined in Europe. Undersowing barley with ryegrass resulted in increased recruitment of Bembidion sp. (Carabidae). An improved microclimate for survival and not the existence of more prey was considered the reason for the greater recruitment (62). Partial weediness in winter wheat fields had no effect on aphid-specific predators and parasitoids but did increase numbers of several species of carabids and staphylinids $(104,105)$. Plant community composition and physical structure (probably partly due to their influence on microclimate) are important in determining the abundance of some coccinellids in wheat fields in Europe (66). In North America the abundance of the coccinellid $H$. convergens increased with increasing broadleaf weed density in spring wheat fields (33).

\section{MEDIATING EFFECTS OF LANDSCAPE MANIPULATIONS ON BIOLOGICAL CONTROL}

\section{Simulation of the Role of the Broader Landscape}

Several studies have considered the role of the broader landscape in determining the abundance of natural enemies of aphids in cereals. The majority of these studies involve simulation modeling focusing on spatially subdivided, interacting natural enemy populations within heterogeneous agricultural landscapes (58, 136). Modeling studies highlight the importance of factors such as the size and spatial distribution of agricultural and nonarable fields and the characteristics of disturbance regimes resulting from agricultural operations in determining natural enemy abundance. The simulations highlight the critical importance of knowledge of species dispersal dynamics in assessing the effects of landscape structure on population dynamics. However, ecological knowledge for most natural enemies is too incomplete for simulation modeling to provide a reliable assessment of effects of landscape manipulation on population dynamics within the landscape.

\section{Empirical Studies of Landscape Structure}

A few empirical studies have addressed the effects of landscape structure on natural enemies of aphids in cereals. Honek (66) observed that the abundance of adult coccinellids in agricultural fields depended on landscape position in the early spring but not later in the growing season. This effect was presumably related to the location of some fields close to wooded habitats, which allowed coccinellids emigrating from these overwintering sites to colonize fields early in the growing season. Later in the growing season, when coccinellids had presumably dispersed more homogeneously across the landscape, landscape position had no effect. Elliott et al. (33) also observed that in a predominately agricultural landscape the presence of wooded land was important in determining adult coccinellid abundance in cereal fields in spring. Landscape effects on abundance were evident at several 
spatial scales. Because of their relatively low levels of dispersal, Coleomegilla maculata Timberlake and Hippodamia parenthesis (Say) responded to variation in landscape structure at a relatively fine spatial scale, whereas the more vagile $C$. septempunctata and $H$. convergens were affected by variation occurring at broader scales (33).

With respect to parasitoids, Vorley \& Wratten (139) demonstrated that dispersal of parasitoids from ryegrass and early-planted winter wheat fields occurred and that parasitoids from these fields comprised a substantial proportion of the adult parasitoids in spring wheat during aphid colonization. Other studies identified cultivated crops or plants in noncrop communities with aphids that serve as alternative hosts for cereal aphid parasitoids $(102,122,124)$, but these studies did not demonstrate that parasitoids from alternative hosts actually dispersed to cereal fields and parasitized cereal aphids.

\section{CONCLUSIONSAND FUTURE RESEARCH}

The predator and parasitoid fauna associated with cereal aphids in North America appears much richer than indicated by surveys conducted before the classical biological control effort against Russian wheat aphid, the most recent example of a damaging cereal aphid invading North America $(37,102,131)$. The complexity of the natural enemy fauna associated with cereal aphids is generally comparable to fauna found in Europe $(8,10,41,102,123,148)$, and it is arguable whether the introduced enemies contributed substantially to biological control by preexisting native and previously introduced natural enemies that are adapting to the new aphid invasions. Discussions of classical biological control programs against future cereal aphid invasions in North America should carefully consider the potential for the current natural enemy fauna to utilize a new cereal aphid or one expanding in its geographic range $(92,123)$.

Better understanding of the mediating effects of host plant and habitat manipulations may accelerate our ability to plan cereal production systems with improved ability to suppress cereal aphids, including future invading species. Comparing cereal breeding lines that are near-isogenic and differ only in a single trait with potential tritrophic effects should aid in discerning the effects of plant characteristics (such as tolerance-related and antibiotic plant characteristics) that appear to affect the functioning of natural enemies $(44,47,85,90,98,110,111)$. Habitat manipulations within and bordering cereal fields and within the broader landscape in which cereal production resides can improve the effectiveness of cereal aphid biological control. Effects on natural enemies of cereal aphids of adding components of aggregated and dispersed diversity in cereal systems depend substantially on the form of the diversity and natural enemy ecology.

Habitat manipulation at the farm level is constrained by farm machinery, erosion and water factors, and economic considerations. Pest management considerations have not been typically considered in the design, although substantial work in Europe and some work in North America are possible indications of more unified 
approaches $(1,39,65,97,100,149)$. Understanding the role of the broader landscape in determining the species composition, distribution, and abundance of natural enemies of aphids in cereals is hampered by substantial obstacles. These include insufficient knowledge of cereal aphid-natural enemy interactions at the broad spatial scale typical of agricultural landscapes in cereal growing regions and potential economic and cultural impediments to change in agricultural practices.

Complementary agricultural (agronomic and pest management) and land-use planning approaches are needed to increase our current state of knowledge of cereal production systems that suppress cereal aphids through enhancing biological control $(1,22,74,84,97,117,118,134)$. The mediating effects of host plant and habitat manipulations on cereal aphid biological control provide significant and underexplored avenues to optimize cereal aphid management.

\section{ACKNOWLEDGMENTS}

We thank T. Noma for assistance in preparing the bibliography. Preparation of this review was partly supported by a grant from the USDA CSREES National Research Initiative Biologically-based pest management program (agreement no. 2000-02559).

\section{The Annual Review of Entomology is online at http://ento.annualreviews.org}

\section{LITERATURE CITED}

1. Ahern RG, Brewer MJ. 2002. Effect of different wheat production systems on the presence of two parasitoids (Hymenoptera: Aphelinidae; Braconidae) of the Russian wheat aphid in the North America Great Plains. Agric. Ecosyst. Environ. 92:201-10

2. Archer TL, Cate RH, Eikenbary RD, Starks KJ. 1974. Parasitoids collected from greenbugs and corn leaf aphids in Oklahoma in 1972. Ann. Entomol. Soc. Am. 67:11-14

3. Boethel DJ, Eikenbary RD, eds. 1986. Interactions of Plant Resistance and Parasitoids and Predators of Insects. New York: Ellis Horwood

4. Bosque-Pérez NA, Johnson JB, Schotzko DJ, Unger L. 2002. Species diversity, abundance, and phenology of aphid natural enemies on spring wheats resistant and susceptible to Russian wheat aphid. BioControl 47:667-84
5. Bottrell DG, Barbosa P, Gould F. 1998. Manipulating natural enemies by plant variety selection and modification: a realistic strategy? Annu. Rev. Entomol. 43: 347-67

6. Bowie MH, Gurr GM, Hossain Z, Baggen LR, Frampton CM. 1999. Effects of distance from field edge on aphidophagous insects in a wheat crop and observations on trap design and placement. Int. J. Pest Manage. 45:69-73

7. Brewer MJ, Mornhinweg DW, Huzurbazar S. 1999. Compatibility of insect management strategies: Diuraphis noxia abundance on susceptible and resistant barley in the presence of parasitoids. BioControl 43:479-91

8. Brewer MJ, Nelson DJ, Ahern RG, Donahue JD, Prokrym DR. 2001. Recovery and range expansion of parasitoids (Hymenoptera: Aphelinidae and Braconidae) released for biological control 
of Diuraphis noxia (Homoptera: Aphididae) in Wyoming. Environ. Entomol. 30:578-88

9. Brewer MJ, Struttmann JM, Mornhinweg DW. 1998. Aphelinus albipodus (Hymenoptera: Aphelinidae) and $\mathrm{Di}$ aeretiella rapae (Hymenoptera: Braconidae) parasitism on Diuraphis noxia (Homoptera: Aphididae) infesting barley plants differing in plant resistance to aphids. Biol. Control 11:255-61

10. Burd J, Shufran K, Elliott N, French W, Prokrym D. 2001. Recovery of imported hymenopterous parasitoids released to control Russian wheat aphids in Colorado. Southwest. Entomol. 26:23-31

11. Burd JD, Burton RL, Webster JA. 1993. Evaluation of Russian wheat aphid (Homoptera: Aphididae) damage on resistant and susceptible hosts with comparisons of damage ratings to quantitative plant measurements. J. Econ. Entomol. 86:974-80

12. Burn AJ. 1988. Effects of scale on the measurement of pesticide effects on invertebrate predators and predation. In Field Methods for the Study of Environmental Effects of Pesticides, ed. MP Greaves, PW Grieg-Smith, BD Smith, pp. 109-17. Croydon, UK: Monogr. No. 40, Br. Crop Prot. Counc.

13. Burton RL, Jones OR, Burd JD, Wicks GA, Krenzer EGJ. 1987. Damage by greenbug (Homoptera: Aphididae) to grain sorghum as affected by tillage, surface residues, and canopy. J. Econ. Entomol. 80:792-98

14. Burton RL, Krenzer EGJ. 1985. Reduction of greenbug (Homoptera: Aphididae) populations by surface residues in wheat tillage studies. J. Econ. Entomol. 78:390-94

15. Canard M, Semeric Y, New TR. 1984. Biology of Chrysopidae. The Hague: Junk

16. Carmona DM, Landis DA. 1999. Influence of refuge habitats and cover crops on seasonal activity-density of ground beetles (Coleoptera: Carabidae) in field crops. Environ. Entomol. 28:1145-53

17. Carter NI, McLean FG, Watt AD, Dixon AFG. 1980. Cereal aphids: a case study and review. In Advances in Applied Biology, ed. TH Coaker, pp. 271-348. New York: Academic

18. Chambers RJ, Adams THL. 1986. Quantification of the impact of hoverflies (Diptera: Syrphidae) on cereal aphids in winter wheat: an analysis of field populations. J. Appl. Ecol. 23:895-904

19. Chambers RJ, Sunderland KD, Stacey DL, Wyatt IJ. 1986. Control of cereal aphids in winter wheat by natural enemies: aphid-specific predators, parasitoids and pathogenic fungi. Ann. Appl. Biol. 108:219-31

20. Chiverton PA. 1986. Predator density manipulation and its effects on populations of Rhopalosiphum padi (Hom.: Aphididae) in spring barley. Ann. Appl. Biol. 109:49-60

21. Chiverton PA. 1988. Searching behaviour and cereal aphid consumption by Bembidion lampros and Pterostichus cupreus in relation to temperature and prey density. Entomol. Exp. Appl. 47: 173-82

22. Chiverton PA, Sotherton NW. 1991. The effects on beneficial arthropods of the exclusion of herbicides from cereal crop edges. J. Appl. Ecol. 28:1027-39

23. Clark TL, Messina FJ. 1998. Foraging behavior of lacewing larvae (Neuroptera: Chrysopidae) on plants with divergent architectures. J. Insect Behav. 11:303-17

24. Collins KL, Boatman ND, Wilcox A, Holland JM, Chaney K. 2002. Influence of beetle banks on cereal aphid predation in winter wheat. Agric. Ecosyst. Environ. 93:337-50

25. Coombes DS, Sotherton NW. 1986. The dispersal and distribution of polyphagous predatory Coleoptera in cereals. Ann. Appl. Biol. 108:461-74

26. Cowgill SE, Wratten SD, Sotherton NW. 
1993. The effects of weeds on the numbers of hoverfly (Diptera: Syrphidae) adults and the distribution and composition of their eggs in winter wheat. Ann. Appl. Biol. 123:499-515

27. Dean GJ. 1983. Survival of some aphid (Hemiptera: Aphididae) predators with special reference to their parasites in England. Bull. Entomol. Res. 73:469-80

28. Dhuyvetter KC, Thompson CR, Norwood CA, Halvorson AD. 1996. Economics of dryland cropping systems in the Great Plains: a review. J. Prod. Agric. 9:216-22

29. Duffield SJ, Aebischer NJ. 1994. The effects of spatial scale of treatment with dimethoate on invertebrate population recovery in winter wheat. J. Appl. Ecol. 31:263-81

30. Edwards CA, Sunderland KD, George KS. 1979. Studies on polyphagous predators of cereal aphids. J. Appl. Ecol. 16:811-23

31. Elliott NC, Burd JD, Armstrong JS, Walker CB, Reed DK, Peairs FB. 1995. Release and recovery of imported parasitoids of the Russian wheat aphid in eastern Colorado. Southwest. Entomol. 20:125-29

32. Elliott NC, Hein GL, Carter MR, Burd JD, Holtzer TO. 1998. Russian wheat aphid (Homoptera: Aphididae) ecology and modeling in Great Plains agricultural landscapes. See Ref. 108a, pp. 3164

33. Elliott NC, Kieckhefer RW, Lee J-H, French BW. 1998. Influence of withinfield and landscape factors on aphid predator populations in wheat. Landsc. Ecol. 14:239-52

34. Farid A, Johnson JB, Quisenberry SS. 1997. Compatibility of a coccinellid predator with a Russian wheat aphid resistant wheat. J. Kans. Entomol. Soc. 70:114-19

35. Farid A, Johnson JB, Shafii B, Quisenberry SS. 1998. Tritrophic studies of Russian wheat aphid, a parasitoid, and resistant and susceptible wheat over three parasitoid generations. Biol. Control 12:1-6

36. Farid A, Quisenberry SS, Johnson JB, Shafii B. 1998. Impact of wheat resistance on Russian wheat aphid and a parasitoid. J. Econ. Entomol. 91:334-39

37. Feng M-G, Johnson JB, Halbert SE. 1992. Parasitoids (Hymenoptera: Aphidiidae and Aphelinidae) and their effect on aphid (Homoptera: Aphididae) populations in irrigated grain in southwestern Idaho. Environ. Entomol. 21:1433-40

38. Fernandes OA, Wright RJ, Mayo ZB. 1998. Parasitism of greenbug (Homoptera: Aphididae) by Lysiphlebus testaceipes (Hymenoptera: Braconidae) in grain sorghum: implications for augmentative biological control. J. Econ. Entomol. 91:1315-19

39. Firbank LG, Carter N, Darbyshire JF, Potts GR, eds. 1991. The Ecology of Temperate Cereal Fields. London: Blackwell Sci. 469 pp.

40. Frank T, Nentwig W. 1995. Ground dwelling spiders (Araneae) in sown weed strips and adjacent fields. Ecologica 16:179-93

41. French BW, Elliot NC. 1999. Temporal and spatial distribution of ground beetle (Coleoptera: Carabidae) assemblages in grasslands and adjacent wheat fields. Pedobiologia 43:73-84

42. French BW, Elliott NC, Berberet RC. 1998. Reverting Conservation Reserve Program lands to wheat and livestock production: effects on ground beetle (Coleoptera: Carabidae) assemblages. Environ. Entomol. 27:1323-35

43. French W, Elliott N, Kindler D, Arnold D. 2001. Seasonal occurrence of aphids and natural enemies in wheat and associated crops. Southwest. Entomol. 26:4961

44. Fuentes-Contreras E, Niemeyer HM. 1998. DIMBOA glucoside, a wheat chemical defense, affects host acceptance and suitability of Sitobion avenae 
to the cereal aphid parasitoid Aphidius rhopalosiphi. J. Chem. Ecol. 24:371-81

45. Fuentes-Contreras E, Niemeyer HM. 2000. Effect of wheat resistance, the parasitoid Aphidius rhopalosiphi, and the entomopathogenic fungus Pandora neoaphidis, on population dynamics of the cereal aphid Sitobion avenae. Entomol. Exp. Appl. 97:109-14

46. Fuentes-Contreras E, Pell JK, Niemeyer HM. 1998. Influence of plant resistance at the third trophic level: interactions between parasitoids and entomopathogenic fungi of cereal aphids. Oecologia 117:426-32

47. Fuentes-Contreras JE, Powell W, Wadhams LJ, Pickett JA, Niemeyer HM. 1996. Influence of wheat and oat cultivars on the development of the cereal aphid parasitoid Aphidius rhopalosiphi and the generalist aphid parasitoid Ephedrus plagiator. Ann. Appl. Biol. 128:181-87

48. Gaimari SD, Turner WJ. 1997. Behavioral observations on the adults and larvae of Leucopis ninae and L. gaimarii (Diptera: Chamaemyiidae), predators of Russian wheat aphid, Diuraphis noxia (Homoptera: Aphididae). J. Kans. Entomol. Soc. 70:153-59

49. Gardner SM, Dixon AFG. 1985. Plant structure and the foraging success of Aphidius rhopalosiphi (Hymenoptera: Aphidiidae). Ecol. Entomol. 10:171-79

50. Giles KL, Jones DB, Royer TA, Elliott NC, Kindler SD. 2003. Development of a sampling plan in winter wheat that estimates cereal aphid parasitism levels and predicts population suppression. J. Econ. Entomol. 96:975-82

51. Gilstrap FE. 1997. Importation biological control in ephemeral crop habitats. Biol. Control 10:23-29

52. Gilstrap FE, Brooks GW, Kring TJ. 1984. Status of greenbug biological control in Texas sorghum. Rep. MP-1538, Texas Agric. Exp. Stn. Misc. Publ.

53. Gilstrap FE, Kring TJ, Brooks GW.
1984. Parasitism of aphids (Homoptera: Aphididae) associated with Texas sorghum. Environ. Entomol. 13:1613-17

54. Gonzáles WL, Gianoli E, Niemeyer HM. 2001. Plant quality vs. risk of parasitism: within-plant distribution and performance of the corn leaf aphid, Rhopalosiphum maidis. Agric. For. Entomol. 3:29-33

55. Gowling GR, van Emden HF. 1994. Falling aphids enhance impact of biological control by parasitoids on partially aphid-resistant plant varieties. Ann. Appl. Biol. 125:233-42

56. Greenstone MH. 2001. Spiders in wheat: first quantitative data for North America. BioControl 46:439-54

57. Halbert SE, Johnson JB, Graves PL, Marsh PM, Nelson D. 1996. Aphidius uzbekistanicus (Hymenoptera: Aphidiidae) established in Idaho. Pan-Pac. Entomol. 72:13-16

58. Halley JM, Thomas CFG, Jepson PC. 1996. A model for the spatial dynamics of linyphiid spiders in farmland. J. Appl. Ecol. 33:471-92

59. Hawthorne A, Hassell M. 1995. The effect of cereal headland treatments on carabid communities. In Arthropod Natural Enemies in Arable Land. I. Density, Spatial Heterogeneity and Dispersal, ed. S Toft, W Riedel, pp. 185-98. Denmark: Aarhus Univ. Press

60. Helenius J. 1990. Effect of epigeal predators on infestation by the aphid Rhopalosiphum padi and on grain yield of oats in monocrops and mixed intercrops. Entomol. Exp. Appl. 54:225-36

61. Helenius J. 1990. Incidence of specialist natural enemies of Rhopalosiphum padi (L.) (Hom., Aphididae) on oats in monocrops and mixed intercrops with faba bean. J. Appl. Entomol. 109:13643

62. Helenius J, Holopainen J, Muhojoki M, Pokki P, Tolonen T, Venalainen A. 1995. Effect of undersowing and green manuring on abundance of ground beetles 
(Coleoptera, Carabidae) in cereals. Acta Zool. 196:156-59

63. Hickman JM, Wratten SD. 1996. Use of Phacelia tanacetifolia strips to enhance biological control of aphids by hoverfly larvae in cereal fields. J. Econ. Entomol. 89:832-39

64. Holland JM, Thomas SR, Hewitt A. 1996. Some effects of polyphagous predators on an outbreak of cereal aphid (Sitobion avenae F.) and orange wheat blossom midge (Sitodoplosis mosellana Gehin). Agric. Ecosyst. Environ. 59:181-90

65. Holtzer T, Anderson RL, McMullen MP, Peairs FB. 1996. Integrated pest management of insects, plant pathogens, and weeds in dryland cropping systems of the Great Plains. J. Prod. Agric. 9:200-8

66. Honek A. 1982. Factors which determine the composition of field communities of adult aphidophagous Coccinellidae (Coleoptera). Z. Angew. Entomol. 94:157-68

67. Hopper K, Randolph T, Boylan J, Cepaitis A, Fauvergue X. 1994. Natural enemy impact on Diuraphis noxia (Mordvilko) (Homoptera: Aphididae) in northeastern Colorado compared to southern France. Proc., The Sixth Russian Wheat Aphid Workshop, Fort Collins, CO: Colo. State Univ.

68. Hopper KR, Aidara S, Agret S, Cabal J, Coutinot D. 1995. Natural enemy impact on the abundance of Diuraphis noxia (Homoptera: Aphididae) in wheat in southern France. Environ. Entomol. 24:402-8

69. Hopper KR, Coutinot D, Chen K, Kazmer DJ, Mercadier G. 1998. Exploration for natural enemies to control $D i$ uraphis noxia (Homoptera: Aphididae) in the United States. See Ref. 108a, pp. 166-82

70. House GJ, Parmelee RW. 1985. Comparison of soil arthropods and earthworms from conventional and no-tillage agroecosystems. Soil Tillage Res. 5:351-60
71. Huusela-Veistola E. 1998. Effects of perennial grass strips on spiders (Araneae) in cereal fields and pesticide side effects. J. Appl. Entomol. 122:575-83

72. Jackson HB, Coles LW, Wood EA Jr, Eikenbary RD. 1970. Parasites reared from the greenbug and corn leaf aphid in Oklahoma in 1968 and 1969. J. Econ. Entomol. 63:733-36

73. Jackson HB, Rogers CE, Eikenbary RD. 1971. Colonization and release of Aphelinus asychis, an imported parasite of the greenbug. J. Econ. Entomol. 64:1435-38

74. Jmhasly P, Nentwig W. 1995. Habitat management in winter wheat and evaluation of subsequent spider predation on insect pests. Acta Oecol. 16:389-403

75. Jones DJ. 2001. Natural enemy thresholds for greenbug, Schizaphis graminum (Rondani), on winter wheat. MS thesis. Oklahoma State Univ.

76. Kauffman WC, LaRoche S. 1994. Searching activities by coccinellids on rolled wheat leaves infested by the Russian wheat aphid. Biol. Control 4:290-97

77. Kieckhefer RW, Kantack BH. 1988. Yield losses in winter grains caused by cereal aphids (Homoptera: Aphididae) in South Dakota. J. Econ. Entomol. 81:317-21

78. Kindler SD, Jensen KB, Springer TL. 1993. An overview: resistance to the Russian wheat aphid (Homoptera: Aphididae) within the perennial Triticeae. $J$. Econ. Entomol. 86:1609-18

79. Knutson A, Boring EP, Michels GJ. 1993. Biological control of insect pests in wheat. Rep. B-5044, Texas Agric. Ext. Serv. Publ.

80. Kring TJ, Gilstrap FE, Michels GJ. 1985. Role of indigenous coccinellids in regulating greenbugs (Homoptera: Aphididae) on Texas grain sorghum. J. Econ. Entomol. 78:269-73

81. Lattin JD. 1989. Bionomics of the Nabidae. Annu. Rev. Entomol. 34:383400

82. Lattin JD. 2000. Minute pirate bugs 
(Anthocoridae). In Heteroptera of Economic Importance, ed. CW Schaefer, AR Panizzi, pp. 607-37. Boca Raton, FL: CRC Press

83. Laubscher JM, Von Wechmar MB. 1993. Assessment of aphid lethal paralysis virus as an apparent population growthlimiting factor in grain aphids in the presence of other natural enemies. Biocontrol Sci. Technol. 3:455-66

84. Lys J-A, Zimmermann M, Nentwig W. 1994. Increase in activity density and species number of carabid beetles in cereals as a result of strip-management. $E n$ tomol. Exp. Appl. 73:1-9

85. Martos A, Givovich A, Niemeyer HM. 1992. Effect of DIMBOA, an aphid resistance factor in wheat, on the aphid predator Eriopis connexa Germar (Coleoptera: Coccinellidae). J. Chem. Ecol. 18: 469-79

86. McConnell JA, Kring TJ. 1990. Predation and dislodgement of Schizaphis graminum (Homoptera: Aphididae) by adult Coccinella septempunctata (Coleoptera: Coccinellidae). Environ. Entomol. 19:1789-802

87. Messina FJ, Hanks JB. 1998. Host plant alters the shape of the functional response of an aphid predator (Coleoptera: Coccinellidae). Environ. Entomol. 27:1196-202

88. Messina FJ, Jones TA, Nielson DC. 1995. Host plant affects the interaction between the Russian wheat aphid and a generalist predator, Chrysoperla carnea. J. Kans. Entomol. Soc. 63:313-19

89. Messina FJ, Jones TA, Nielson DC. 1997. Host-plant effects on the efficacy of two predators attacking Russian wheat aphids (Homoptera: Aphididae). Environ. Entomol. 26:1398-404

90. Messina FJ, Sorenson SM. 2001. Effectiveness of lacewing larvae in reducing Russian wheat aphid populations on susceptible and resistant wheat. Biol. Control 21:19-26

91. Michels GJ, Behle RW. 1992. Evalua- tion of sampling methods for lady beetles (Coleoptera: Coccinellidae) in grain sorghum. J. Econ. Entomol. 85:2251-57

92. Michels GJ, Elliot NC, Romero RA, Owings DA, Bible JB. 2001. Impact of indigenous coccinellids on Russian wheat aphids and greenbugs (Homoptera: Aphididae) infesting winter wheat in the Texas panhandle. Southwest. Entomol. 26:97-114

93. Michels GJ, Whitaker-Deerberg RL. 1993. Recovery of Aphelinus asychis, an imported parasitoid of Russian wheat aphid, in the Texas panhandle. Southwest. Entomol. 18:11-16

94. Michels GJ. 1986. Graminaceous North American host plants of the greenbug with notes on biotypes. Southwest. Entomol. 11:55-66

95. Mohamed AH, Lester PJ, Holtzer TO. 2000. Abundance and effects of predators and parasitoids on the Russian wheat aphid (Homoptera: Aphididae) under organic farming conditions in Colorado. Environ. Entomol. 29:360-68

96. Nentwig W. 1989. Augmentation of beneficial arthropods by strip-management. II. Successional strips in a winter wheat field. J. Plant Dis. Prot. 96:89-99

97. Nentwig W, Frank T, Lethmayer C. 1998. Sown weed strips: artificial ecological compensation areas as an important tool in conservation biological control. In Conservation Biological Control, ed. P Barbosa, pp. 396-420. New York: Academic

98. Niemeyer HM, Perez FJ. 1995. Potential of hydroxamic acids in the control of cereal pests, diseases and weeds. In Allelopathy: Organisms, Processes, and Applications, ed. Inderjit, KMM Dakshini, FA Einhellig, pp. 260-70. Washington, DC: Am. Chem. Soc.

99. Parajulee MN, Montandon R, Slosser JE. 1997. Relay intercropping to enhance abundance of insect predators of cotton aphid (Aphis gossypii Blover) in Texas cotton. Int. J. Pest Manage. 43:227-32 
100. Peterson GA, Schlegel AJ, Tanaka DL, Jones OR. 1996. Precipitation use efficiency as affected by cropping and tillage systems. J. Prod. Agric. 9:180-86

101. Pike KS, Schaffner RL. 1985. Development of autumn populations of cereal aphids, Rhopalosiphum padi (L.) and Schizaphis graminum (Rondami) (Homoptera: Aphididae) and their effects on winter wheat in Washington state. $J$. Econ. Entomol. 78:676-80

102. Pike KS, Starý P, Miller T, Allison D, Boydston L, et al. 1997. Smallgrain aphid parasitoids (Hymenoptera: Aphelinidae and Aphidiidae) of Washington: distribution, relative abundance, seasonal occurrence, and key to known North American species. Environ. Entomol. 26:1299-311

103. Pike KS, Starý P, Miller T, Graf G, Allison D, et al. 2000. Aphid parasitoids (Hymenoptera: Braconidae: Aphidiinae) of Northwest USA. Proc. Entomol. Soc. Wash. 102:688-740

104. Powell W, Dean GJ, Dewar A. 1985. The influence of weeds on polyphagous arthropod predators in winter wheat. Crop Prot. 4:298-312

105. Powell W, Dean GJ, Wilding N. 1986. The influence of weeds on aphid-specific natural enemies in winter wheat. Crop Protect. 5:182-89

106. Powell W, Wilding N, Brobyn PJ, Clark SJ. 1986. Interference between parasitoids (Hym.: Aphidiinae) and fungi (Entomophthorales) attacking cereal aphids. Entomophaga 31:293-302

107. Powell W, Wright AF. 1988. The abilities of the aphid parasitoids Aphidius ervi Halliday and A. rhopalosiphi De Stefani Perez (Hymenoptera: Braconidae) to transfer between different known host species and the implications for the use of alternative hosts in pest control strategies. Bull. Entomol. Res. 78:683-93

108. Prokrym DR, Pike KS, Nelson DJ. 1998. Biological control of Diuraphis noxia (Homoptera: Aphididae): implementa- tion and evaluation of natural enemies. See Ref. 108a, pp. 183-208

108a. Quisenberry SS, Peairs FB, eds. 1998. Proceedings of Response Model for an Introduced Pest-The Russian Wheat Aphid. Lanham, MD: Entomol. Soc. Am.

109. Reed DK, Kindler SD, Springer TL. 1992. Interactions of Russian wheat aphid, a hymenopterous parasitoid, and resistant and susceptible slender wheatgrasses. Entomol. Exp. Appl. 64:239-46

110. Reed DK, Webster JA, Jones BG, Burd JD. 1991. Tritrophic relationships of Russian wheat aphid (Homoptera: Aphididae), a hymenopterous parasitoid (Diaeretiella rapae McIntosh), and resistant and susceptible small grains. Biol. Control 1:35-41

111. Rice ME, Wilde GE. 1988. Experimental evaluation of predators and parasitoids in suppressing greenbugs (Homoptera: Aphididae) in sorghum and wheat. Environ. Entomol. 17:836-41

112. Rice ME, Wilde GE. 1991. Aphid predators associated with conventionaland conservation-tillage winter wheat. $J$. Kans. Entomol. Soc. 64:245-50

113. Rogers CE, Jackson HB, Eikenbary RD, Starks KJ. 1972. Host-parasitoid interaction of Aphis helianthi on sunflowers with introduced Aphelinus asychis, Ephedrus plagiator, and Praon gallicum, and native Aphelinus nigritus and Lysiphlebus testaceipes. Ann. Entomol. Soc. Am. 65:38-41

114. Schaefer CW, Dysart RJ, Specht HB. 1987. North American distribution of Coccinella septempunctata (Coleoptera: Coccinellidae) and its mass appearance in coastal Delaware. Environ. Entomol. 16:368-73

115. Schoonhoven LM, Jermy T, van Loon JA. 1998. Insect-Plant Biology: From Physiology to Evolution. Chapman \& Hall. 409 pp.

116. Schuster DJ, Starks KJ. 1975. Preference of Lysiphlebus testaceipes for greenbug resistant and susceptible small 
grain species. Environ. Entomol. 4:88788

117. Sotherton NW. 1984. The distribution and abundance of predatory arthropods overwintering on farmland. Ann. Appl. Biol. 105:423-29

118. Sotherton NW. 1985. The distribution and abundance of predatory Coleoptera overwintering in field boundaries. Ann. Appl. Biol. 106:17-21

119. Starks KJ, Burton RL. 1977. Preventing greenbug outbreaks. Rep. No. 309, USDA Sci. Educ. Admin. Leaflet. Washington, DC

120. Starks KJ, Muniappan R, Eikenbary RD. 1972. Interaction between plant resistance and parasitism against the greenbug on barley and sorghum. Ann. Entomol. Soc. Am. 65:650-55

121. Starks KJ, Wood EAJ, Burton RL. 1974. Relationships of plant resistance and Lysiphlebus testaceipes to population levels of the greenbug [Schizaphis graminum] on grain sorghum. Environ. Entomol. 3:950-52

122. Starý P. 1983. The perennial stinging nettle (Urtica dioica) as a reservoir of aphid parasitoids (Hymenoptera, Aphididae). Acta Entomol. Bohemoslov. 80:8186

123. Starý P. 1999. Parasitoids and biocontrol of Russian wheat aphid, Diuraphis noxia (Kurdj.) expanding in central Europe. $J$. Appl. Entomol. 123:273-79

124. Starý P, González D. 1991. The Chenopodium aphid, Hayhurstia atriplicis (L.) (Hom., Aphididae), a parasitoid reservoir and a source of biocontrol agents in pest management. J. Appl. Entomol. 111:243-48

125. Stoetzel MB. 1987. Information on and identification of Diuraphis noxia (Homoptera: Aphididae), and other aphid species colonizing leaves of wheat and barley in the United States. J. Econ. Entomol. 80:696-704

126. Summy KR, Gilstrap FE, Corcoran SM. 1979. Parasitization of greenbugs and corn leaf aphids in west Texas. Southwest. Entomol. 4:176-80

127. Sunderland K, Samu F. 2000. Effects of agricultural diversification on the abundance, distribution, and pest control potential of spiders: a review. Entomol. Exp. Appl. 95:1-13

128. Sunderland KD, Fraser AM, Dixon AFG. 1986. Field and laboratory studies on monkey spiders (Linyphidae) as predators of cereal aphids. J. Appl. Ecol. 23:433-47

129. Symondson WOC, Sunderland KD, Greenstone MH. 2002. Can generalist predators be effective biocontrol agents? Annu. Rev. Entomol. 47:561-94

130. Tanasijtshuk VN. 1996. Two species of Leucopis Meigen (Diptera: Chamaemyiidae) predacious on the Russian wheat aphid, Diuraphis noxia (Mordvilko) (Homoptera: Aphididae), in North America. Proc. Entomol. Soc. Wash. 98:64046

131. Tanigoshi LK, Pike KS, Miller RH, Miller TD, Allison D. 1995. Search for, and release of, parasitoids for the biological control of Russian wheat aphid in Washington state (USA). Agric. Ecosyst. Environ. 52:25-30

132. Tenhumberg B. 1995. Estimating predatory efficiency of Episyrphus balteatus (Diptera: Syrphidae) in cereal fields. Environ. Entomol. 24:687-91

133. Tenhumberg B, Poehling HM. 1995. Syrphids as natural enemies of cereal aphids in Germany: aspects of their biology and efficacy in different years and regions. Agric. Ecosyst. Environ. 52:3943

134. Thomas MB, Sotherton NW, Coombes DS, Wratten SD. 1992. Habitat factors influencing the distribution of polyphagous predatory insects between field boundaries. Ann. Appl. Biol. 120: 197-202

135. Thomas MB, Wratten SD, Sotherton NW. 1991. Creation of 'island' habitats in farmland to manipulate populations 
of beneficial arthropods-predator densities and species composition. J. Appl. Ecol. 29:524-31

136. Topping CJ. 1997. Predicting the effect of landscape heterogeneity on the distribution of spiders in agroecosystems using a population dynamics driven landscape-scale simulation model. Biol. Agric. Hortic. 15:325-36

137. van Emden HF. 1986. The interaction of plant resistance and natural enemies: effects on populations of sucking insects. See Ref. 3, pp. 138-50

138. Vickerman GP, Wratten SD. 1979. The biology and pest status of cereal aphids (Hemiptera: Aphididae) in Europe: a review. Bull. Entomol. Res. 69:132

139. Vorley VT, Wratten SD. 1987. Migration of parasitoids (Hymenoptera: Braconidae) of cereal aphids (Hemiptera: Aphididae) between grassland, earlysown cereals and late-grown cereals in southern England. Bull. Entomol. Res. 77:555-68

140. Walker AL, Bottrell DG, Cate JRJ. 1973. Hymenopterous parasites of biotype $C$ greenbug in the High Plains of Texas. Ann. Entomol. Soc. Am. 66:173-76

141. Wallin H. 1985. Spatial and temporal distribution of some abundant carabid beetles (Coleoptera: Carabidae) in cereal fields and adjacent habitats. Pedobiologia 28:19-34

142. Webster JA. 1995. Economic impact of the greenbug in the western United States: 1992-1993. Rep. Vol. Publ. No. 155, Great Plains Agric. Counc., Stillwater, Okla.

143. Webster JA, Kenkel P. 1999. Benefits of managing small-grain pests with plant resistance. In Economic, Environmental, and Social Benefits of Resistance in Field Crops, ed. BR Wiseman, JA Webster, pp. 59-86. Lanham, MD: Entomol. Soc. Am.

144. Webster JA, Porter DR, Baker CA, Mornhinweg DW. 1993. Resistance to Russian wheat aphid (Homoptera: Aphididae) in barley: effects on aphid feeding. J. Econ. Entomol. 86:1603-8

145. Winder L. 1990. Predation of the cereal aphid Sitobion avenae by polyphagous predators on the ground. Ecol. Entomol. 15:105-10

146. Wissinger SA. 1997. Cyclic colonization in predictably ephemeral habitats: a template for biological control in annual crop systems. Biol. Control 10:4-15

147. Wratten SD. 1987. The effectiveness of native natural enemies. In Integrated Pest Management, ed. AJ Brown, TH Coaker, PC Jepson, pp. 89-112. London: Academic

148. Wratten SD, Powell W. 1991. Cereal aphid and their natural enemies. See Ref. 39, pp. 233-57

149. Wratten SD, Thomas CFG. 1990. Farmscale spatial dynamics of predators and parasitoids in agricultural landscapes. In Species Dispersal in Agricultural Habitats, ed. R Bunce, pp. 219-37. London: Bellhaven

150. Xia J. 1994. An integrated cotton insect pest management system for cottonwheat intercropping in North China. Proc. World Cotton Res. Conf. I. Challenging the Future, ed. GA Constable, NW Forest, pp. 511-17. Brisbane, Aust. $617 \mathrm{pp}$. 